članica DPK PM za angleščino

mira.hladnik@gmail.com

\title{
SCHOOL ENCOUNTERS WITH MARK HADDON'S NOVEL The Curious Incident of the Dog in the Night-Time (2003)
}

\section{BEFORE STEP-BY-STEP READING}

One of the aims that reading and dealing with this novel targets is preparing our students better to understand people with special needs, especially those suffering from Asperger's Syndrome (AS) or a high-functioning form of autism.

- Activity: Find examples of the following potential behavioural symptoms ${ }^{1}$ in Christopher, the protagonist of the novel The Curious Incident of the Dog ... :

a. Inclination to order (e.g., numbers, lists, charts ...)

b. Too much attention to detailed descriptions

c. Poor or no understanding of facial gestures

d. Inability of imagination and understanding imaginary events

e. Preference not to communicate but to be alone and quiet

f. Repulsion at being touched or cuddled

g. Inability to sort out and respond to too much information

h. Tantrums (like screaming, hitting) for no apparent reason

i. Oversensitivity of the five senses: noise, smell, touch, light (colour), taste

j. Black-white picturing of the world (dog-people, good day colours-black day colours)

k. Talent for logical thinking (deepened knowledge of exact sciences)

1. Inability to understand metaphors, idioms, jokes, puns, vulgar language ...

$\mathrm{m}$. Difficulty in mixing with counterparts

n. Unawareness to the seriousness of a situation (e.g., danger)

o. Repetition of moves or words (without grasping the actual meaning)

p. Inappropriate attachment to objects, animals instead to people

- Activity: Read this excerpt from the Slovene article dealing with Asperger's Syndrome and establish some similarities between Tomaž and Christopher.

Verjemi, sprejmi, izobražuj se in nikoli se ne predaj (Lisa, 29. 9. 2005) 
"Ime mi je Tomaž. Star sem 10 let. Včasih se mi zdi, da sem drugačen kot drugi otroci. Čeprav se mi to na zunaj ne vidi. Mamica mi je povedala, da imam avtizem. In da bom to imel vse življenje. Rekla je, da bom zrastel, hodil v šolo in šel v službo kot drugi otroci. Včasih vem, kaj mi govori. Včasih pa sploh ne razumem njenih besed. Kot če bi bil v kakšni drugi državi, kjer govorijo čisto drugačen jezik. Slišim besede, pa ne vem, kaj pomenijo. Ampak to je samo včasih. Včasih se mi zdi vse okoli mene preglasno. Pa čeprav mami reče, da je vse tiho. Pokrijem si ušesa. In včasih me zaboli, ko me kdo poboža. Včasih se mi kdo posmehuje. Mama pravi, da to ni lepo. Da se to ne dela. Ampak jaz mislim, da smeh pomeni, da je človek prijazen. Rad imam vodo. In rad plavam. Rad grem igrat tenis. Pa včasih sploh ne vem, kaj moram narediti. Ampak tam so tudi otroci in lahko sem z njimi. Velikokrat pa mi je lepše, če sem čisto sam. Vsak dan se mi zdi kot igra, ki se je moram naučiti. In ta igra ima zelo težka pravila. Ampak se bom naučil.”2 Films that feature characters with AS, like: Mercury Rising (1998, directed by Harold Becker), Rain Man (1988, directed by Barry Levinson), etc. can also help us slip inside Christopher's head.

- Activity: When watching the film Rain Man jot down some typical autistic attitudes, as well as some mistakes the character played by Tom Cruise makes in relating to his autistic brother.

\section{READING}

Home reading is carried out in more or less even chunks; the students are assigned to answer the questions found below within a reasonable period of time. Their anwers are discussed in pairs on the appointed date.

Note: Instead repeating the name Christopher, $\mathrm{C}$ is used. The words Father and Mother are capitalized when used as proper names. The numbers in brackets at the end of items refer to page numbers of the Red Fox Definitions edition, 2004.

\section{Pages 1-34; chapters 2-47}

1. Who narrates/writes the story? What kind of story does he create? (2)

2. Who is Christopher? (age, his interests, abilities and disabilities)

3. Describe the situation a few minutes after midnight in front of Mrs Shears' house. $(1,7)$

4. What do we learn about the dog? (4)

5. Who do you think Siobhan is? What is $\mathrm{C}^{\prime}$ 's attitude to her like? $(2,3,5)$

6. What is interesting about the chapter numbers?

7. Why does he decide to write about a dog's murder, not a human's one? (6)

8. How does $\mathrm{C}$ feel about the police? (7)

9. How does he react when being held tight by a police officer? (8-9)

10. What happens at the police station? (17)

\footnotetext{
2 Center za avtizem. 10. oktober 2011. www.avtizem.org.
} 
11. How does he spend the night in the police cell? (17)

12. What does $\mathrm{C}$ think about metaphors? (20)

13. How do $\mathrm{C}$ and his father show affection for each other? (21)

14. How often does $C$ tell lies? $(23,24)$

15. Who is Toby? (27)

16. Who does C live with? Where is his mother? (28-29)

\section{Pages 35-64; chapters 53-79}

1. What kind of a get-well card does $\mathrm{C}$ send to his mother to hospital? Colour? (35)

2. Why was mother's heart attack unexpected? (36)

3. C. contemplates 2 types of heart attack; what is the style like: objective or subjective?

4. Why does Mrs Shears come over to $\mathrm{C}$ and Father more often after his mum's death?

5. C is attracted by details (e.g people's clothes). Justify with the examples on the pages $37,39,42,47,50$.

6. $\mathrm{C}$ is also crazy about numbers and geometry. Justify with the examples on the pages 37,51 ,

7. Why does $\mathrm{C}$ decide for himself what he is or is not going to do? Give C's examples of people's breaking the rules. (38)

8. C takes words literally. How does he perceive his dad's words:"Stay out of other people's business."? (38)

9. Whose orders can $\mathrm{C}$ understand very well and why? (39)

10. C knows all the countries, their capitals and prime numbers up to 7,507. What is on TV when he drops by Mrs Shears' house? How does she accept him? What detective work does he do at the Shears' shed? What has he found out? What does Mrs Shears threaten C with when she notices him? (39-41)

11. What disagreement does $\mathrm{C}$ have with the Reverend Peters regarding heaven and god? Where is his mother now, in C's opinion? (42-44)

12. What do $\mathrm{C}$ and his dad usually do on Saturdays? What's dad doing this Saturday? And what has $\mathrm{C}$ decided to do? (45)

13. What does $\mathrm{C}$ carry for feeling safer? (45)

14. Why is he afraid of strangers? Is it because of Stranger Danger? What questions does $\mathrm{C}$ ask people when he finally decides to approach them? (46-53)

15. Does $\mathrm{C}$ watch people's faces when talking to them? What about eye contact? (47)

16. What activity of his does $\mathrm{C}$ find very brave? (46)

17. C loves plans, lists, charts ... Find an example of each and describe them.

18. C loses his temper very quickly; he becomes aggressive towards others. Does he hit only in self-defence? Give examples $(45,56)$

19. C investigates door to door about anything that might clear up the murder of Wellington. Which people has he talked to? What does he learn from them?

20. C is oversensitive to smell, too. Give an example? (49) 
21. As $\mathrm{C}$ writes his detective mystery novel, he puts down exact words-e.g., $\mathrm{Mr}$ Thompson said, "I haven't a bloody clue." What is C's reaction to the vulgar words, like "bloody hell," "fucking dog," etc.?

22. What does $\mathrm{C}$ do when people laugh at him? (50)

23. $\mathrm{C}$ manages reasonable, logical, literal communication. What does $\mathrm{C}$ think of chatting? And what does he say to Mrs Alexander when she offers him some sweets? (51-53))

24. Does C trust people-e.g., Mrs Alexander? What is he afraid of? (51)

25. After a step-by-step logical reasoning $\mathrm{C}$ comes to his Prime Suspect? Who is it and on what basis has he been suspected? (53-54)

26. What does $C$ like and what does he dislike about Mrs Shears' visits? (54-55)

27. What idiomatic meaning do the following Mrs Shears' sentences have: "I am going to hit the hay." "It's brass monkeys out there." "Let's rustle up some tucker." (55)

28. Children can get very cruel. What do they call $\mathrm{C}$ and his school-mates?

29. How does Father achieve that $\mathrm{C}$ can take A level in Maths? What mark does $\mathrm{C}$ expect? What plans does $\mathrm{C}$ have for the future? (56-58)

30. $\mathrm{C}$ is proud of himself because he is more grown up. In what sense? (59)

31. Why did their parents often argue? (59)

32. He has listed his behavioural problems that used to drive his parents out of their minds. What is C's opinion of the moral rule that you always have to tell the truth? What stupid and dangerous things has he done? Give examples? (60)

33. C is fussy about food servings? What doesn't he like on his plate? (62)

34. C tells Father a white lie. But it's already clear to dad where C's been. How does he react when $\mathrm{C}$ mentions Mr Shears as Prime Suspect? What does C have to promise dad? (64)

\section{Pages 65-99; chapters 83-113}

1. Why does he think he would make a good astronaut? Does he often contemplate being on his own? C's attitude to yellow and brown? What would he take with him into space? (65)

2. What do Siobhan and $\mathrm{C}$ talk about? Why is he sad? How does he behave when he has a Black Day? (67)

3. Five red cars in a row make a Super Good Day. Who does $C$ meet in the shop? What does he learn from her about Mr Shears and his mother? C says to Mrs Alexander that he can't do the chatting. And what does he like doing? Why does he feel uneasy in the company of Mrs Alexander? (69-77)

4. Why does Mr Jeavons think that $\mathrm{C}$ likes maths? How does $\mathrm{C}$ explain The Monty Hall problem? Are the chances of winning a car $33 \%$ to $66 \%$ after one door has been opened, or $50 \%$ to $50 \%$ ? Does he favour intuition or logic? (78-82)

5. Who is Rhodri and what does he look like? His smell? What makes Rhodri speechless? What advice does Siobhan give $\mathrm{C}$ about his novel writing? What descriptions has he already included in his writing? What does he compare the cloud with? What noises does he hear? (83-87)

6. The Hound of the Baskervilles by Conan Doyle is C's favourite book. Who are the following characters from this detective novel and what are their relation- 
ships: Sherlock Holmes, Doctor Watson, Dr James Mortimer, Hugo, Charles and Henry Baskerville, the Stapletons, Barrymore, Selden. C says he isn't interested in faces, that he is intelligent and able to concentrate, just like Sherlock Holmes. C likes dogs, but what does he say about the hound of the Baskervilles? C loves reasoning, logic, lists; what are the two lists about? (88-93)

7. After reading his book, Siobhan offers help to $\mathrm{C}$. Why might he need help? Why doesn't $\mathrm{C}$ feel upset about the affair between his mother and Mr Shears? Does he ever tell lies? What has he drawn?

8. What does C compare his memory with? What is smelltrack? Which event of July 4th, 1992 does he recall? Does he like taking off his clothes? What body contact does he have with his parents? Does he like phrases that don't make any sense-e.g., You'll catch your death in that. Can he imagine things that haven't happened to him? (96-98)

\section{Pages 100-144, chapters $127-157^{3}$}

1. How does Dad realize that $C$ is still investigating Wellington's murder? (101)

2. What is a rhetorical question? (102)

3. How does $\mathrm{C}$ react when Father grabs him? (103)

4. What does Father do with the book? (104)

5. Why does $\mathrm{C}$ hate yellow? (105)

6. And why does he dislike brown? (106)

7. Why do they go to the zoo the next day? (108)

8. Why does $\mathrm{C}$ believe that his Father loves him? (109)

9. Where does $\mathrm{C}$ find his book? (117)

10. What else does he come across there? (118)

11. What is unusual about the way C's name is written on the envelopes? (119)

12. Who is the letter from and what is it about? (122)

13. What is C's second mystery he has to solve? (124)

14. How does $\mathrm{C}$ feel about mysteries in general? (124-125)

15. Does he try to solve the letter mystery at once? (124)

16. What happens at his school meanwhile? (129)

17. How many letters, addressed to him, does $C$ find? (131)

18. What are they about? (121-122, 131-141)

19. Describe the incident in the shop at Christmas time. $(133,134)$

20. Who is more patient: C's mother or father? (134)

21. How does mother react when $C$ refuses to eat for days? $(135,136)$

22. And what is C's reaction like? (136)

23. Find a few spelling mistakes in the letters from p.131 to 136.

24. Why doesn't she say good-bye to C before disappearing? (137)

25. Why has she moved to London? (137)

26. How often does she write letters to C? (138)

27. What else has she sent him? (140)

28. What was C's experience with the dentist like? (141)

3 Z dovoljenjem so vprašanja od 100. strani dalje prirejena oz. povzeta iz izročkov prof. Marjete Papler. 
29. How does $\mathrm{C}$ feel after reading all the letters and how does he react? (141, 142)

30. What does Father say to $\mathrm{C}$ when he finds out that he has read the letters? (143)

31. What is unusual about C's behaviour when Father changes his wet clothes and puts him in a bath, touching him? (144)

\section{Pages 145-220; chapters 163-223}

1. What does $C$ think of computers? (145-148)

2. How does C calm himself down while Father is cleaning the mess? (149)

3. What shocking confession does Father make in order to convince $\mathrm{C}$ that he is going to speak the truth from now on? (150)

4. How does Father explain to $C$ the reasons for this cruel action? (151)

5. How does $\mathrm{C}$ accept Father's offer to touch fingers after the confession? (152)

6. What does $\mathrm{C}$ do at night? (154)

7. Who does he want to live with at first and how does he justify his decision? (160-161)

8. Why does he look in on Mrs Alexander? (164-166)

9. Who does he want to ask the way to the train station? (170)

10. Describe how $\mathrm{C}$ feels at the local train station. (180-181)

11. How does the conversation with a policeman turn out? (184-188)

12. How does $C$ feel about timetables and schedules? (192-193)

13. What does $C$ expect the police officer to do when he tells him that his father is waiting for him at the police station? (196-197)

14. What happens to $C$ on the way to London? (200-207)

15. What is in the bag that has disappeared with the police officer? (207)

16. How does he feel at the underground station compared to the train station? (217)

17. How does he react to the crowds there? (216-219)

\section{Pages 221-272: chapters 227-233, Appendix}

1. How long does $C$ spend waiting for the tube? (221)

2. What happens meanwhile with Toby? (223-224)

3. How does Mother react when she sees him? (233-234)

4. What does $C$ say about not answering Mother's letters? (236)

5. Who comes over a few moments after $\mathrm{C}$ has taken a bath? (237)

6. And who comes over at night? (239)

7. What's C's favourite dream he has that night? (242)

8. What is "compassionate leave"? (245)

9. Why does $C$ want to return to Swindon the very next day? (249)

10. What happens to C's mother at work? (249)

11. How do Mother and Mr Shears get along since C has arrived? (251-252)

12. What does C's mother decide to do? (253)

13. Can C take his A-level Maths now? Why? (254)

14. How does $C$ feel about the cancellation of the exam? (255) 
15. Who helps him take the exam after all? (257)

16. What happens meanwhile?

17. What can't $\mathrm{C}$ understand about his father?

18. Where do $\mathrm{C}$ and his mother live since their return to Swindon? (262)

19. And what happens to Toby? (264)

20. What does Father do in an attempt to reconcile with his son? (266)

21. What are his exam results like? (266)

22. What plans about schooling does he have? (267)

23. Which three goals has $\mathrm{C}$ reached in his life? (268)

\section{Suggested answers:}

\section{Pages 1-34}

1. The novel is narrated from the point of view of Christopher Boone, who introduces himself to the reader at the beginning of the novel. One can immediately notice that there is something extraordinary about him, as he is so good at memorizing numbers and facts (e.g., countries' and capital cities' names), while on the other hand he needs help with reading facial gestures. He creates a murder mystery novel similar to the ones with detective Sherlock Holmes. His teacher Siobhan has asked him to write about the events that he has experienced starting with an event that would »grab people's attention.«

2. Christopher is a 15-year old boy afflicted with autism. He is talented in math, astronomy, physics, and geography; he is good at precise observation but has problems with communication (he can't read facial gestures, he avoids eye contact, doesn't undertand jokes, metaphors, idioms properly) and socializing (he abhors being touched, being in a crowd, being asked too many questions at a time).

3. C comes across the neighbours' dog Wellington lying dead in blood with a garden fork sticking out of his body. He picks the dog up and holds him for some time. When Mrs Shears sees what has happened, she starts screaming.

4. The dog is a black poodle that belongs to Mr and Mrs Shears, the Boones' neighbours.

5. Siobhan is one of C's teachers at the school for students with special needs, and the one who $\mathrm{C}$ trusts the most as she always knows how to deal with his feelings, his shortcomings and abilities. She often gives him advice on his book writing.

6. The chapters are numbered with prime numbers; they are the numbers that remain when all the multiples are taken away: $2,3,5,7,11,13,17$, etc. $\mathrm{C}$ is obviously hooked on math. »Prime numbers are like life. They are very logical but you could never work out the rules, even if you spent all your time thinking about them.«(15)

7. C cares a lot about dogs because, in comparison to people, they are faithful, honest, do not tell lies and are sometimes even cleverer than people. 
8. C likes the police because they wear uniforms, and it is always clear what their duties are.

9. During interrogation the policeman even suspects $\mathrm{C}$ of killing the dog. When $\mathrm{C}$ starts rolling in the lawn and groaning because of being asked too many questions at a time, the policeman takes hold of $C^{\prime}$ s arm, which $C$ can't stand, so he hits him.

10. At the police station $\mathrm{C}$ was arrested for assaulting the police officer and put into a cell where he observes the cell as a geometric phenomenon. Soon Father comes to take $\mathrm{C}$ home.

11. Metaphors are like lies to him because he interprets them literally.

12. Look at the exercise on the page 19.

13. They spread out fingers in a fan and make them touch each other.

14. C never tells lies because he can't imagine things that are not real.

15. Toby is C's unusual pet, a rat he is inseparable with.

16. C lives in a terrace house with his father, a plumber. His mother was, according to Father, very ill and died shortly after spending some time in hospital.

\section{Pages 35-64}

1. The get-well card has lino cut pictures of red cars on the front; the red colour should make a Super Super Good Day for Mother.

2. Mother was only 38. C is puzzled A as heart attacks usually happen to older people, and apart from that, she ate healthy food.

3. C discusses two types of heart attacks: embolism (clotting of blood) and aneurysm (blood vessels break); the style of listing facts is objective.

4. Mrs Shears helps with housekeeping and tries to comfort C's father.

5. Mrs Shears was wearing sandals, jeans and a T-shirt. (37) Mrs Shears was wearing sheepskin slippers and she had been watching a quiz programme ... (39) Mrs Forbes wears tracksuit trousers ... (42) Mr Thompson was wearing a T-shirt which said: »Beer. Helping ugly people have sex ...«. (47). Mrs Alexander was wearing jeans /.../ And there was mud on the jeans /.../ And the laces were red. (50)

6. I beat her (i.e., Mrs Shears) 247 points to 134 . (37); my age is 15 years and 3 months and 3 days. (51)

7. People often tell $\mathrm{C}$ what (not) to do, but they don't tell exactly, why, where, for how long etc. So $\mathrm{C}$ decides to make decisions by himself. Also people often break the rules (e.g., Father often overspeeds; Crusaders killed people in the name of Christianity ...)

8. C does a lot of things together with others, especially at school; he understands Dad's warning »Stay out of other people's business « literally.

9. C can understand Siobhan's instructions very well, because she tells exactly what he is allowed and not allowed to do.

10. There is a quiz on countries' capitals on TV. Mrs Shears isn't hospitable at all. $\mathrm{C}$ has a look into the Shears' shed where he sees the fork Wellington has been stabbed with. As a real detective $\mathrm{C}$ does some resoning: the murderer must have had the key to the shed. Mrs Shears threatens $\mathrm{C}$ to call the police again. 
11. C wants to know where heaven is, but Reverend Peters is not very convincing when answering that heaven is not in our universe and when people die they are united with god. He postpones talking about whereabouts of god onto some other time. Mother's molecules must be somewhere over Africa ... and they come down as rain or snow.

12. Usually Father takes $C$ on an outing, but this Saturday he is watching a football game Romania vs. England on TV. C decides to do some more detective work on his own.

13. He can't go anywhere without his Swiss Army knife.

14. C doesn't like people he has never met before. Otherwise he can defend himself very well against nasty people (by hitting back, by using his Swiss Army knife. It takes weeks before $C$ asks new staff members questions, like Do you have pets at home? What's your favourite colour? What car do you drive? etc.

15. C doesn't look at the face of a person he is talking to-e.g., to Mr Thompson.

16. He finds talking to unknown people is a very brave deed.

17. There is a plan of Randolph Street (46) and a list of C's behavioural problems $(59,60)$

18. C once punched Sarah for pulling his hair so hard that she had concussion (45). If other children call $\mathrm{C}$ and his friends from school »Special Needs, « »Spaz, $\mathrm{Crip}$, « $\mathrm{C}$ is ready to get very cruel in self-defence (56)

19. C knocks onto several doors in his neighbourhood: he speaks to Mr Thomson, the black lady (who says $\mathrm{C}$ should ask his dad about Wellington's murder), Mr Wise, Mrs Alexander (who goes to fetch juice and biscuits for him but $\mathrm{C}$ walks away before she reappears). $\mathrm{C}$ doesn't learn any relevant data from them.

20. Mr Wise smells of body odour and old biscuits.

21. He doesn't react to vulgar language at all - he seems to overhear it.

22. He turns around and walks away.

23. When people chat their questions and answers don't seem connected to C. He says he doesn't know if he likes Battenberg biscuits with marzipan icing because he has never tried them.

24. C doesn't trust people because of Stranger Danger (e.g., potential sexual abuse), so he doesn't want to enter Mrs Alexander's house.

25. Mr Shears has become C's Prime Suspect because he knew Wellington well and he disliked Mrs Shears, so it must have been him who wanted to make her sad.

26. Mrs. Shears keeps their home tidy, which $C$ likes but he doesn't like her smoke or say confusing things, like »hit the hay«, etc.

27. hit the hay - iti spat; brass monkeys = mrzlo vreme; rustle up some tucker/ chow $=$ napraskati nekaj hrane

28. They call them spaz, crip, mong, special needs ...

29. C's father strongly demands from the headmistress to enable $C$ take A level in Math. C expects an A grade. C intends to take A-level further Math and Physics and then go to universitiy to another town. He plans to find a job and get married. 
30. Because they had to look after someone with behavioural problems, which was very stressful.

31. C thinks that he is more grown up as he can take decisions for himself and can do things on his own.

32. C states that it's not always nice to tell people the truth-e.g., saying to someone you don't like him or her ... The stupid things he has done: spreading peanut butter all over the table, burning shoes on the stove, etc.

33. Different sorts of food mustn't touch each other when served.

34. C doesn't tell Dad that he has been doing some detective work, but he just says he has been out. But Father has already learnt everything from Mrs Shears. He tells $\mathrm{C}$ not to mention Mr Shears's name ever again. He makes C to promise him to give up the detective game and not to stick his nose into other people's business.

\section{Pages 65-99}

1. He could become an astronaut because he understands how machines work, is intelligent and is happy to be alone far away from other people. He also likes being in small, closed places, like sitting on his own in the airing cupboard. If there wasn't any yellow or brown in his spacecraft, it would be ok. He'd take his pet rat with him.

2. C and Siobhan talk about what his dad has told him not to do, i.e. detective work. They also discuss the book passages he has written. C is frustrated because he still doesn't know who the murderer is. When he has a Black Day, he sits in a corner for hours refusing to speak to anyone.

3. C meets Mrs Alexander in a shop; he learns from her that his mother and $\mathrm{Mr}$ Shears had an affair. $\mathrm{C}$ tells her he likes space, Maths and computers, taking care of Toby, being on his own, but can't do the chatting. Mrs Alexander is a stranger to $\mathrm{C}$, so he feels uneasy in her company.

4. $\mathrm{MrJ}$. thinks that $\mathrm{C}$ is into mathematics because it's safe and it requires solving problems which always have an answer in the end. C favors logical thinking over intuition. The chances to win the car are 2 times out of $3(66 \%)$ after one door has been opened.

5. Rhodri is Father's work companion. He wears white dungarees with dirt all over them. He smells of paste he and his father use at work. When $\mathrm{C}$ does complicated multiplication calculations by heart, Rhodri remains speechless. Siobhan says $\mathrm{C}$ should include some descriptions of things into his book. C has already described some people's looks, their smell, the way of acting. He compares the clouds with fish scales, sand dunes, alien spaceships ...

6. Sherlock Holmes and Mr Watson are detectives. Dr Mortimer is a medical doctor from Devon. Hugo Baskervilles, Charles Baskerville's ancestor, died under weird circumstances. Henry B. is Charles's heir. Mr Stapleton, who is related to the Baskervilles, is an evil man who has planned to kill the Baskervilles so that he would inherit their Hall. Mrs Stapleton is his wife, not his sister, as he has made people believe. Barrymore is the Baskervilles' Hall caretaker, Selden is the Notting Hill murderer (and the brother of Barrymore's wife). The hound that has been occasionally seen 
in the marshes, is believed to be a huge beast that kills innocent people. $\mathrm{C}$ has composed 2 lists: a list of clues and a list of red herrings (neprava sled).

7. C might need help when he feels sad because his mother has cheated on his father. C doesn't feel sad, though he is not sad because his mother is dead or because Mrs Shears isn't around anymore. C never tells lies. He has drawn some pictures of aliens.

8. His memory is like a film. Smelltrack is like a soundtrack. He clearly remembers what certain people looked like, what they were wearing, what they smelt like. $\mathrm{C}$ and his mother were on the beach in Cornwall on 4 July and he was afraid his mum might have been eaten by a shark, so he screamed, although there are no sharks in Cornwall. He doesn't like taking off his clothes. $\mathrm{C}$ and his parents touch each other so that they spread out their fingers in a fan. $\mathrm{C}$ doesn't like phrases because he can't understand them; he can't grasp things that haven't happened, either.

\section{Pages 100-144}

1. Father notices the book on the kitchen table $\mathrm{C}$ has left when being absorbed in watching the Blue Planet video.

2. According to Siobhan, $\mathrm{C}$ knows that a rhetorical question is a question the person asking it already knows the answer.

3. C hits father, and then he probably passes out for a short time.

4. Father walks out into the garden and throws the book into the dustbin

5. Because he dislikes custard, bananas, double yellow lines, yellow fever, yellow flowers, sweet corn.

6. Because dirt, gravy, poo, wood are brown, and he dislikes the girl Melissa Brown because she tore his astronaut painting.

7. Father wants to show his remorse. It's a rainy day, which is good because C wouldn't like crowds at the zoo, usual on sunny days.

8. Because Father has never lied to him, he has come to the police station to fetch him, and he cooks for him.

9. C finds it in a plastic shirt box in the father's room.

10. C comes across a bunch of letters addressed to him.

11. It has circles instead of dots on i, typical of only 3 persons: Siobhan, his exteacher of C's and his mother.

12. They are from Mother. She is writing how she works as a secretary for a steel products factory in London and about her living with Roger Shears.

13. Now he has to solve two mysteries: who has murdered Wellington and who are the letters from if Mother is believed to be dead. C wonders how come the Mother's letter was sent 18 months after her death.

14. He is totally confused and intrigued by them. He wants to find answers and scientific explanations.

15. Only after six days when he has a chance to resume searching the Father's room.

16. His schoolmate Joseph Fleming eats everything, from money to poo. C doesn't want to use the pupils' toilet and wets his pants; therefore he is allowed to use the staff toilet for a few days. 
17. C finds 43 letters addressed to him.

18. They are about Mother's memories of the times spent together. And the second was about why she has left $\mathrm{C}$ and his father.

19. C didn't feel well due to too many people so he started shouting and when mother wanted to pick him up, he broke the things around and wetted himself, so Mother had to pay for the two broken mixers.

20. Father is much more patient and not so hot-tempered as Mother.

21. She freaks out and throws the food around the room.

22. C hits her foot with the chopping board and breaks her toes. She has to get plaster, but Father blames her for getting cross with $\mathrm{C}$

23. Here are some spelling mistakes from the letters (131-136): waist (waste), differant (different), timetabels (timetables), pacient, (patient), maniger (manager), stoped (stopped), argumant (argument), realy (really), your (you are), puzles (puzzles), etc.

24. Father doesn't let her enter the house or speak to Christopher, either.

25. Because Roger gets a job there in a bank; she also gets attached to Mr Shears, who seems to understand her problems.

26. Mother writes $C$ approximately once a week.

27. Once she sent him a puzzle.

28. C had to be put to sleep so that the dentist could pull one of his teeth out.

29. C feels giddy and his stomach hurts. He can't explain why Father has been lying to him. He throws up and a moment later passes out, so he has no recollection of the event later, »as if a bit of the tape had been erased « (142).

30. Father is very sorry; he tries to explain $\mathrm{C}$ why he has chosen to lie to him, but $\mathrm{C}$ throws up again.

31. C doesn't resist when being touched and doesn't hit Father, either.

\section{Pages 145-220}

1. Because, unlike people, computers don't have minds but can do plenty of other things that people do: forecast weather, talk to people, even tell jokes.

2. He doubles $2 \mathrm{~s}$ in his head and that calms him. He comes to 2 to $25^{\text {th }}$ power, which is less than he has managed before: 2 to $45^{\text {th }}$ power.

3. Father confesses that he has killed Wellington.

4. Father was jealous of the dog because Mrs. Shears paid more attention to the dog than to Father and C. So he did it after a bad row with Mrs Shears.

5. C pushes Father away and screams.

6. C escapes to the garden shed with Toby. There he feels safe. He describes the Orion constellation in detail. In the morning he hears Father calling his name, but he hides from him.

7. Mrs Shears because she is a friend, not a stranger; he wants to tell her that Father has killed the dog. But she isn't at home. So he decides to look for his mother. The idea of going to London on his own frightens him but it's the only acceptable option.

8. C wants to leave Toby with her and tells her about who has killed Wellington. When she goes to call his father, he escapes. At home he breaks the door glass, takes Father's credit card, as he knows that without money he won't make it. 
9. C wants to ask Siobhan but, spotting Father's "maintenance \& boiler repair" van outside school, he feels sick again. Finally he asks a lady with a pushchair where to buy a map of the area. She kindly shows him the way to the railway station.

10. Being very confused, $\mathrm{C}$ reacts with groaning; $\mathrm{C}$ does a maths problem to relax.

11. When a police officer asks him some "difficult" questions-e.g., "Anyone at home? Are you all right?" C replies with No. The "easy questions," like asking for his name and address, calm him down. Then he withdraws some money and finally manages to buy a ticket.

12. They comfort him, "they make sure you don't get lost in time."

13. C expects that Father will be arrested for killing Wellington.

14. C has to use the toilet and the officer lets him do that as he has already wetted his pants. Then he hides on a shelf among the bags to feel safe; he does equations in his head. A lady sees him, and a drunken man later on, but luckily, the officer can't find him.

15. The bag contains Toby's food, maths books, clean pants, orange juice, clementines, custard creams, baked beans.

16. C feels even worse on the tube because it is much more crowded.

17. He groans, sweats and feels sick when a man's clothes touch his knees coincidentally. He would prefer to be at home if it wasn't for his father, who he is afraid of even more than the crowds on the tube. He analyses advertisements to get calmed down (e.g., the one for a dream holiday in Malaysia). He feels secure if events are organised.

\section{Pages 221-272}

1. About 5 hours because he doesn't dare enter the tube; he's totally insecure.

2. C looks for Toby, finds it in a gap between the rail and the curb. In the last moment $\mathrm{C}$ is saved by a man with diamond patterned socks, but $\mathrm{C}$ hits him for touching him. Finally $\mathrm{C}$ decides to get on the next train with the rat in his pocket.

3. Mother isn't at home so $\mathrm{C}$ waits for her behind a dustbin under a tree and when she comes, accompanied with Mr Shears, she tries to hug C, but he pushes her away; then she remembers that $C$ hates being touched.

4. C explains that Father has lied to him about her having died of a heart attack; further on $\mathrm{C}$ tells Mother that he has found her letters only recently.

5. A police officer wants to confirm C's story. C is allowed to stay with his mother.

6. At night Father comes and wants to speak to C's mother. She reproaches him for lying to $\mathrm{C}$. He wants $\mathrm{C}$ to touch each other's fingers but the boy is frightened and refuses to do so. The police are called and Father has to leave.

7. C has dreamt that all the people catch a sort of a computer virus and die out. There are only few left who don't pay attention at other people and don't know the meaning of the icons $(-):-2$. C can go anywhere in the world and nobody touches him. 
8. Employees can take it if someone in their family is ill or dies. C's mother takes it for her son's sake.

9. Because he has to sit the A-level Math exam. Mother says he can't do that and he starts feeling a pain in his chest at the thought.

10. She gets fired.

11. They often argue; once $\mathrm{Mr}$ Shears gets drunk and reproaches $\mathrm{C}$ for being selfish.

12. Mother decides to go home to Swindon with C. It takes about 3 hours by car.

13. No, he can't take the Maths A-level test because his mother has phoned school and called it off. She doesn't know yet if they'll return for good.

14. C feels terribly upset, physically aching.

15. Siobhan helps again. It takes 3 days.

16. Mr Shears comes by taxi, throws a box of Mother's things onto the lawn and leaves in his own car.

17. C wonders why Father isn't arrested for killing Wellington. He would only be arrested if Mrs Shears pressed charges against him. And killing a dog is a "little crime," according to Mother.

18. Mother gets a job in a local garden centre, takes anti-depressives. They move to a room in a big red house. She works until 5.30 and $C$ has to be with Father for two hours; C pushes his bed against the door so Father can't enter. He is still afraid of him.

19. Toby dies, 2 years 7 months old, which is reasonable for a rat.

20. He buys him a puppy, a golden retriever, which C names Sandy.

21. C gets an A-grade!

22. Yes, he wants to take A-level Physics and higher Math, go to university, but not to crowded London. And he would like to become a scientist.

23. He has completed the book, visited his mother in London and found the murderer of Wellington.

- Activity: Continue drawing the action line, following the pattern below. ${ }^{4}$

\begin{tabular}{|c|c|c|c|}
\hline Time & Page & Chapter & Events \\
\hline $\begin{array}{l}7 \text { minutes } \\
\text { after } \\
\text { midnight }\end{array}$ & 1 & 2 & $\begin{array}{l}\text { - The dog, poodle breed, named Wellington is lying dead on } \\
\text { the lawn in front of Mrs Shears' house, stabbed with a garden } \\
\text { fork } \\
\text { - C introduces himself as Christopher Francis Boone, } 15 \text { years, } \\
3 \text { months, } 2 \text { days old } \\
\text { - C mentions his teacher Siobhan who helps him to read facial } \\
\text { expressions by drawing visual icons, (etc.) }\end{array}$ \\
\hline
\end{tabular}

- Activity: Comment the book on the blog. Here is an example: Post $4:^{5}$

Suhadolc, Eva. 10. oktober 2011.www.dijaski.net/.../ang_dob_haddon_mark_the_curious_incident_of_the_.

5 Hladnik, Mira. 10. oktober 2011. http://mira-e-twinning-es.blogspot.com/. 
Dear 3 EG class students, you've been doing so well that we should switch to blogging more often in the future!

Peter's remark that Cristopher's dad should find himself a new wife, respectively a new mum for the boy, is well down-to-earth. Now let's move to the TASK no. 4 !

We can presume that Christopher misses his mother a lot although he doesn't complain and tries not to show his sorrow either.

- Where is she, according to the first hundred pages?

- What have we learned so far about her character, her looks, her actions?

- Can we state that she was a good parent to Christopher?

- Justify whatever you say. I am looking forward to your original comments. Aren't you curious to learn more about the story? In any case, do read on to the page 150. Deadline: 5th February. Posted by Mira at 8:30 AM 13 comments

10:27 AM, tejcika said: Christopher loved his mother. He said that she was very nice and he loved her very much. But I think that she spent too little time with him, probably for this reason because she didn 't love his father anymore. Also, it is true that parents with such children like Christopher need more patience, matual understanding and assistance.

11:27 AM, Dolenc said: Christopher's mother is dead. But he loves his mother. This shows that Chrisopher remembers a scene from the past like it would be happening today.

She was a good mother, but not a good wife. She cheated his husband with Mr Shears. But it is not necessary that this is only her fault. Maybe they had a lot of arguments. (etc.)

- Presentations by individual students, supported by ICT (ppt, applications: Google maps, ...) on the following topics:

Tracking down Christopher's way from Swindon to London

Mathematics ${ }^{6}$ and astrology in the novel

The role of colours, illustrations, patterns, signs, notices in Christopher's life Christopher's attitude to metaphors, lies and jokes, (etc.)

- Main characters

6 KOS, Jasna (2008) How can English final exam make mathematics lessons more interesting or Mathematical aspect of the book The Curious Incident by Mark Haddon, Gimnazija Bežigrad, Ljubljana.

10. oktober 2011. http://www.presek.si/34/index.html. 
Activity: Match the names of the characters with their correspondent descriptions.

\begin{tabular}{|l|l|l|l|}
\hline 1 & Christopher Boone & & C's father, his sole caregiver \\
\hline 2 & Ed Boone & & $\begin{array}{l}\text { golden retriever C gets from his father as a sign of reconcilia- } \\
\text { tion }\end{array}$ \\
\hline 3 & Siobhan & & friendly neighbour who helps C with investigation work \\
\hline 4 & Judy Boone & & neighbour's dog that has been found stabbed in the yard \\
\hline 5 & Eileen Shears & Father's companion in the boiler business \\
\hline 6 & Roger Shears & & teacher who invigilates C during taking his A-Maths test \\
\hline 7 & Mrs Alexander & & C's pet rat C can't do without \\
\hline 8 & Rhodri & & neighbour who helps C's father through crisis \\
\hline 9 & Reverend Peters & & teacher who best understands and encourages C \\
\hline 10 & Mr Jeavons & & Mrs Boone's new intimate partner \\
\hline 11 & Sandy & C's mother who has eloped with another man to London \\
\hline 12 & Wellington & 15 -year old narrator and protagonist of the story \\
\hline 13 & Toby & & is hit by C when he's asked him too many questions at a time \\
\hline 14 & unnamed policeman & & psychologist at C's school \\
\hline
\end{tabular}

Key: $2,11,7,12,8,9,13,5,3,6,4,1,14,10$

- The language of the novel ${ }^{7}$ is rather limited, as Christopher's first-person singular articulation of reality cannot delve into the meaning of numerous idioms and metaphors, which the boy perceives as lies.

7 Carey, Justina (2006) The Autistic spectrum, predavanje na Novostih stroke za učitelje angleščine, Ljubljana: FF 
Activity: Match each idiom with its meaning. Can you imagine what meaning these idioms may convey to an autistic person, i.e. to Christopher in our case?

\begin{tabular}{|l|l|l|l|}
\hline IDIOM (PHRASE) & MEANING & $\begin{array}{l}\text { MEANING for } \\
\text { Christopher }\end{array}$ \\
\hline 1. I laughed my socks off. (19) & mind your own business & \\
\hline 2. He was the apple of her eye. (19) & everything turned into a disaster & \\
\hline 3. I'll hit the sack. (19) & very loudly and vigorously & \\
\hline 4. The dog was stone dead. (19) & a big, shocking secret & \\
\hline $\begin{array}{l}\text { 5. They had a skeleton in the } \\
\text { cupboard. (19) }\end{array}$ & like somebody a lot & \\
\hline 6. We had a real pig of a day. (19) & & lose one's temper & \\
\hline 7. It's brass monkeys out there. (55) & find some food & \\
\hline 8. Don't stick your nose in. (102) & go to bed & $\begin{array}{l}\text { exasperated to the limit of one's } \\
\text { endurance }\end{array}$ \\
\hline 9. Let's rustle up some tucker. (55) & & without any signs of life & \\
\hline 10. I lose my rags. (109) & very cold & \\
\hline 11. I was at the end of my tether.(134) & \\
\hline
\end{tabular}

Key: 8, 6, 1, 5, 2, 10, 9, 3, 11, 4, 7; C understands all the phrases literally.

Activity: Fill in the chart below telling what the main character Christopher

\begin{tabular}{|l|l|l|l|}
\hline CAN DO/is an expert at: & CAN'T DO: & LIKES: & DISLIKES: \\
\hline- & - & - & - \\
- & - & - & - \\
- & - & - & - \\
- & - & - & - \\
\hline
\end{tabular}

\section{POST-READING ACTIVITIES}

\section{a. Dramatized presentation of the novel}

Most beneficial to the students, of course, is if they stage one or more scenes. There are a lot of direct and indirect speech lines which lend themselves to being turned into a play. In case of a shortage of time, there is an English travelling theatre ${ }^{8}$ on hand which willingly stages the played version of »The Dog" at your school. 
- Some role play suggestions which can get filmed and downloaded on youtube (e.g., 10 October 2011. http://www.youtube.com/watch?v=qt3t8ZXZnnc):

Christopher and his neighbour Mrs Alexander when doing his detective work

Christopher and his father when the latter admits killing the dog

Christopher arriving at his mother's apartment in London

Hot chair scenes, e.g. a student in the role of Christopher, others ask him questions, like "Do you like school? Your favourite teacher? Most enjoyable school activities? « etc.

\section{b. Writing suggestions:}

- Informal, formal and semi-formal letters: Mrs Shears' letter to the police asking for intervention in the case of the dog's murder Mother's letter to her lawyer: an application for custody Mother's letter to $\mathrm{Mr}$ Boone when she decides to leave him Siobhan's letter to Christopher's father instructing him on how to treat the boy

- Title suggestions for writing essays (higher level matura, 220-250 words required)

Christopher through somebody else's eyes (e.g. Siobhan's)

In what way is Christopher similar and different from you?

Discuss Mother's relationship with Christopher

How does autism manifest itself in Christopher's behaviour?

Discuss Christopher's words »People want to be stupid and do not want to know the truth.«(113)

What are Christopher's strengths and weaknesses?

Discuss Christopher's pursuit of order and stability in life

Discuss Christopher's journey to London (Matura, spring term 2010) ${ }^{9}$

Discuss Christopher's way of solving problems (Matura, spring term, 2009)

Compare and explain Christopher's attitude towards the people he knows and his attitude towards strangers (Matura, autumn term 2009)

- Argumentative essay titles (basic level matura, 180-220 words required): Both parents have failed their mission to bring up Christopher properly A great deal of Christopher's success is thanks to Siobhan Christopher cannot function as a responsible, independent person In the end the people around Christopher have more problems than bim

\section{c. Some more hints how to bring the novel closer to the readers}

- Suggestions for interdisciplinary lessons (Kovač Flisar:199-213): English classes can be combined with Maths, Psychology, Slovene (e.g., the original compared with the Slovene translation), Philosophy, Geography (e.g., the geographical location of the novel and the way which $C$ has covered).

- Some Slovene secondary schools have dedicated a project week to dealing with various aspects of the novel.

- Exploitation of the novel for grammar practice-e.g.,

9 10. oktober 2011. http://www.ric.si/splosna_matura/predmeti/anglescina/. 
Turn into Indirect Speech:

»Is this your fork? « he asked. $(8) \rightarrow$ He asked $C$ if that was his fork.

Turn into Direct Speech (useful for dramatization purposes):

Then they asked me for Father's phone number. $(17) \rightarrow$ Then they asked me, "What is your father's phone number?«

\section{d. How to test students' acquaintance with the novel}

Make sure that also testing is based on the literary text we are dealing with.

You can use and alter the activities presented above or you can take the advantage of the materials available on the internet (e.g., materials by Razvojna skupina za e-angleščino, ZRSS). ${ }^{10}$

Let me close this open-ended article with Haddon's words, »Every life is narrow. Our only escape is not to run away, but to learn to love the people we are and the world we find ourselves.«

\section{VIRI IN LITERATURA}

HADDON, Mark (2003) The Curious Incident of the Dog in the Night-Time. London: Random House (Red Fox Definitions, edition 2004).

HADDON, Mark (2004) Skrivni primer ali kdo je umoril psa. Ljubljana: Modrijanova knjiga, prevedel Vasja Cerar.

ERŽEN, V. (idr.) (2008). Učni načrt-gimnazija. Angleščina. Ljubljana: Zavod RS za šolstvo.

SUHADOLC, Eva (2006) Gradivo za pripravo na maturo. Predavanje na Novostih stroke za učitelje angleščine, Ljubljana: FF.

PAPLER, Marjeta. 10. oktober 2011. Literature in the matura. ESIC Kranj. http:// esola.esic.si/course/view.php?id=29.

KOVAČ FLISAR, Tanja (2011) Književno delo kot podlaga za medpredmetno povezavo. Eržen, V.(ur.) Posodobitve pouka v gimnazijski praksi. Angleščina. Ljubljana: Zavod za šolstvo.

KOS, Jasna (2006/2007) Je labko matura iz angleščine navdih matematikom ali matematični komentarji h knjigi Skrivnostni primer ali kdo je umoril psa" - Prvi del: Praštevila. Presek, letnik 34.

SEŠEK, Urška/Cvetka SOKOLOV (2001) Pen to Paper, Ljubljana:Rokus

SEGAR, Marc. The battles of the autistic thinker. 10. oktober 2011. http://www.autismandcomputing.org.uk/marc1.en.html.

Aspreger's syndrome symptoms. 10. oktober 2011. http://www.webmd.com/ brain/autism/tc/aspergers-syndrome-symptoms.

Autistic spectrum disorders. 10. oktober 2011. http://www.autism-help.org/aspergers-guide-intro.htm.

$\overline{10}$ Košir, Metka. 10. oktober 2011. http://www2.arnes.si/ ${ }^{2}$ kosir2/studywithus/selfstudy.htm. 
MESCALLADO, Ray (2006) The Curious Incident of the Dog in the Night-Time. 10. oktober 2011. http://monkeynote.stores.yahoo.net/index.html, TheBestNotes.

\section{POVZETEK}

\section{Šolska srečanja z romanom Marca Haddona Skrivnostni primer ali kdo je umoril psa}

Čeprav je na voljo ogromno materialov, ki so nam v pomoč pri poučevanju in proučevanju Haddonovega romana Skrivni primer ali kdo je umoril psa, pa jih tale članek dodaja še nekaj. V prvi vrsti postreže z vprašanji ter predlaga odgovore nanje. Takšen, sicer precej tradicionalen pristop pripravi dijaka, da se bolj natančno poglobi v delo. Nadalje so nanizane ideje za naslove oz. teme esejev, pisem, govornih vaj, iger vlog. Za preverjanje dijakovega razumevanja umetniškega dela je dodanih še nekaj konkretnih nalog. Skratka, gre za skupek raznolikih pristopov in dejavnosti, med katerimi učitelj prosto izbira.

Ključne besede: Aspergerjev sindrom, avtizem, glavni junak, metafora, fraza, osebno pismo, (pol-)uradno pismo, detektivski roman, kriminalka, medpredmetne povezave pri pouku

\section{ABSTRACT}

\section{School encounters with Mark Haddon's novel The Curious Incident of the Dog in the Night-Time (2003)}

This article adds additional materials to the already large corpus available for interpreting and teaching Haddon's novel The Curious Incident of the Dog in the Night-Time. First, the article adheres to a quite copious method of furnishing questions and possible answers to prepare students for more detailed reading of the work. Further, it lists ideas for student essay titles or topics, letters, presentations, and role play activities. Some specific assignments are added to check students' understanding of the artistic work. In short, it offers a complex of diverse approaches and activities from which the teacher may freely choose.

Keywords: Asperger's Syndrome, autism, protagonist, metaphor, idiom, informal letter, (semi-)formal letter, detective novel/whodunit, mystery novel, interdisciplinary classes 